Cahiers d'études africaines

211/2013

Varia

Goody, Jack. - Myth, Ritual and the Oral

Robert Launay

(2) OpenEdition

Journals

Electronic version

URL: http://journals.openedition.org/etudesafricaines/14517

DOI: 10.4000/etudesafricaines. 14517

ISSN: $1777-5353$

Publisher

Éditions de l'EHESS

Printed version

Date of publication: 16 September 2013

Number of pages: $751-752$

ISBN: 978-2-7132-2388-4

ISSN: 0008-0055

Electronic reference

Robert Launay, "Goody, Jack. - Myth, Ritual and the Oral », Cahiers d'études africaines [Online], 211 |

2013, Online since 20 September 2013, connection on 24 September 2020. URL : http://

journals.openedition.org/etudesafricaines/14517; DOI : https://doi.org/10.4000/etudesafricaines.

14517

This text was automatically generated on 24 September 2020

(c) Cahiers d'Études africaines 


\title{
Goody, Jack. - Myth, Ritual and the Oral
}

\author{
Robert Launay
}

\section{REFERENCES}

Goody, Jack. - Myth, Ritual and the Oral. Cambridge, Cambridge University Press, 2010, 186 p., bibl.

1 This is a collection of articles by Goody, most of them published in the last ten years. The title is somewhat misleading. Except for the first chapter as well as a long chapter on the Bagre-a long recitation (actually two separate recitations, the Black Bagre and the White Bagre) which Goody and his collaborators recorded several times and which accompanies initiation ceremonies among the LoDagaa of Ghana-the central concerns of the bulk of the book are neither myth nor ritual, but rather on the question of narrative, both oral and written.

2 Indeed, the entire first chapter "Religion and ritual from Tylor to Parsons: the definitional problem", first published some fifty years ago, seems both out of place and dated. Radcliffe-Brown s and Talcott Parsons pronouncements on religion have by now recede beyond the discipline's horizon and no critique, however justified, seems pertinent to contemporary preoccupations. The one aspect of the article which remains relevant, and which sets the tone for much if not all of the remaining chapters, is its thorough critique of durkheimian sociological reductionism. Another chapter, taking Robert Darnton's (and by extension Clifford Geertz's) work as its target, is an equally sweeping rejection of cultural reductionism. one of the central themes of the collection, reflecting Goody's field work in Ghana among the LoDagaa and the Gonja, is the relative autonomy of oral narrative from either "society" or "culture". For example, even though the Gonja were a state society before British colonization whereas the LoDagaa were acephalous, chiefs figured in LoDagaa folktales about as often (indeed slightly more often) than in Gonja stories Goody collected. Such stories, short and easy to 
remember as they are, were so easily and readily transmitted across social and cultural borders that attempts to use them as in some sense symptomatic of local cultures or societies is futile. Moreover, he insists that such stories were almost always intended for children, and not taken seriously by adults, and thus highly inappropriate as indices of any "cultural" mentality much less ofsystèmes de pensée.On the other hand, the LoDagaa Bagre, while it was taken far more seriously, was also much too long to standardize, and varied so extensively from recitation to recitation that it tended to reflect the individual religious preoccupations of the reciter as much as, if not more than, any standardized social or cultural way of thinking.

3 Not surprisingly, given his preoccupations throughout his long and distinguished career, Goody dwells in many of the chapters on the impact of writing on narrative, including reflections on the simultaneous origins of the novel in eighteenth century Europe and China-a far cry from myth, ritual, or even the oral. Indeed, he calls into question contemporary theorizing (Frederic Jameson is a particular target) about the centrality of narrative to human thought and experience. Narrative, he argues, is far more peripheral to oral societies.

Obviously, writing privileges and standardizes extensive narratives; life histories, for example, are a quintessentially written genre. More pointedly, supposedly oral genres such as epics are, he argues, equally a product of the technology of writing. Indeed, Goody suggests an almost Puritanical (the term is his) suspicion of narrative in oral societies. Here, he extrapolates and generalizes from his own field experience in Ghana, always a risky temptation for anthropologists. His examples, intriguing as they may be, cannot really be conclusive.

The last chapter of the collection, "Writing and oral memory: the importance of the "lecto-oral", is arguably the most interesting and provocative. Here, he suggests that writing not only transforms but in important instances actually promotes the oral transmission of knowledge. Learning "by heart" and consequently reciting from memory is a technique that, after all, depends intrinsically on writing. The religious significance of such recitation in so many scriptural religions-Judaism, Islam, Hinduism, Buddhism among others-attests to the impact on writing on oral performance. In this way, he attempts to complicate the distinction between the written and the oral, rather than simply to dichotomize ways of thinking in terms of technologies of memory. 